\title{
EMERGENCE AND PHYSIOLOGICAL BEHAVIOR OF PROVENANCES OF PINHÃO MANSO IN FUNCTION OF LEVEL OF ALUMINUM
}

\author{
EMERGENNCIA E COMPORTAMENTOFISIOLÓGICO DE PROCEDENCIAS DE \\ PINHÃO MANSO EM FUNÇÃO DE NÍVEIS DE ALUMÍNIO
}

\section{Leandro Henrique de Sousa MOTA ${ }^{1}$; Silvana de Paula Quintão SCALON²; Daiane Mugnol DRESCH ${ }^{3}$; Cesar José da SILVA ${ }^{4}$}

1. Syngenta, Cascavel, State Paraná, Brazil; 2. Faculty of Agricultural Sciences, University of Grande Dourados Dourados, Mato Grosso do Sul, Brazil; 3. Brazilian Agricultural Research Corporation Dourados, State Mato Grosso do Sul, Brazil. silvanascalon@ufgd.edu.br

\begin{abstract}
The aluminum in high levels in the soil affects the emergence, growth, and development of various species. Therefore, the objective of this study was to evaluate the emergence and physiological behavior of four provenances of Jatropha curcas subjected to different levels of aluminum. The experiment was performed in a greenhouse in a completely randomized design, with four levels of aluminum in the soil $\left(8.2,16.5,24.0 \mathrm{mmol}_{\mathrm{c}} \cdot \mathrm{dm}^{-3}\right.$ and control) and four provenances of $J$. curcas seeds $(\mathrm{P} 1=$ Dourados-MS, $\mathrm{P} 2=$ Montes Claros-MG, P3 = Alta Floresta-MT, and P4 = Petrolina-PE); the effects of aluminum toxicity were investigated in $25,50,75$, and 100 days after emergence. The levels of aluminum in the soil were collected from the initial soil correction, which featured an aluminum level of $24.0 \mathrm{mmol}_{\mathrm{c}} \mathrm{dm}^{-3}$. The seedling emergence was not affected by treatment with aluminum; however, the height and leaf area of P1, P2, and P3 were reduced with increasing levels of aluminum. The emergence and vigor of $J$. curcas seeds were not influenced by the differences in the origins of the seeds or by the aluminum levels evaluated. Gas exchanges were affected negatively by aluminum and the responses of the chlorophyll a fluorescence indicate harmful effect in the photosynthetic apparatus. The seeds of origin P4 (Petrolina-PE) has increased tolerance to stress conditions.
\end{abstract}

KEYWORDS: Jatropha curcas L. Oleaginous. Gas exchange. Toxicity.

\section{INTRODUCTION}

\section{Jatropha curcas L. (Euphorbiaceace) has remarkable economic, ecological, and environmental potential; it can be used as a medicinal plant, for protection against soil erosion, and for making hedges (DIVAKARA et al., 2010). At present, its use has been highlighted in biodiesel production (LAVIOLA et al., 2010).}

During plant growth, aluminum is accumulated in the root system, thereby affecting its emergency, growth, and development, the diameter of roots is increased and the number of lateral roots is increased (MACEDO et al., 2011; GORDIN, et al., 2013). This effect could be secondary to aluminum accumulation resulting from the decreased photosynthetic activity and stomatal conductance and altered photochemical and biochemical reactions of $\mathrm{CO}_{2}$ fixation (SOUSA et al., 2012; YANG et al., 2015).

Measurement of gas exchange regulated by stomatal movement allows the determination of photosynthetic rates, although it might not be effective for assessing the deleterious effects of toxic substances on chloroplasts. The reduction in photosynthetic activity due to aluminum toxicity results from the inhibition of photosystem II activity, which might reflect in the form of reduced chlorophyll fluorescence (CAMEJO et al., 2005; DURÃES et al., 2005; YANG et al., 2015).

Fluorescence is one of the three routes of energy dissipation, which includes a small fraction of energy dissipated in the form of light by chlorophyll molecules; this fluorescence can be altered by many factors, including adverse conditions during plant development (STRASSER; TSIMILLI-MICHAEL; SRIVASTAVA, 2004). Hence, this parameter is a sensitive and reliable marker for the evaluation of the photochemical efficiency of photosystems and for the detection and quantification of environmental stresses that affect the activity of the photosynthetic apparatus (CAMEJO et al., 2005).

Plants growing in soils containing aluminum show differential responses via changes in the physiological behavior. The photosynthesis activity of tolerant plant species or cultivars is not affected considerably because of the presence of adjustment strategies that allow the normal functioning of the photosynthetic apparatus even under stress (YANG et al., 2015). Analysis of the photosynthetic potential of a plant and its 
relationship with the environment in which it grows and develops allows the exploration of its adaptability to the cultivation conditions and maximization of its productive potential.

Although the effects of aluminum on plants have long been investigated, the primary mechanisms of toxicity and tolerance have not yet been clarified. Many researchers speculate that the selection of productive and tolerant genotypes to aluminum toxicity is essential to implement management strategies for acidic soils (TABALDI et al., 2007).

Since $J$. curcas is still undergoing domestication in the Cerrado region, few studies have investigated its tolerance to aluminum with concerning the physiological and agronomic effects. Hence, this study aimed to evaluate the physiological behavior of the provenances of $J$. curcas grown in soils containing different levels of aluminum.

\section{MATERIAL AND METHODS}

The experiment was conducted in a greenhouse from January to April, at the Faculty of Agricultural Sciences, Universidade Federal da Grande Dourados, Dourados-MS located at coordinates of latitude $22^{\circ} 11^{\prime} 45^{\prime \prime} \mathrm{S}$ and longitude $54^{\circ} 55^{\prime} 18^{\prime \prime} \mathrm{W}$. During the experimental period, the average temperature and relative humidity in the greenhouse were $26.8^{\circ} \mathrm{C}$ and $72.4 \%$, respectively. The experimental unit consisted of vessels having a capacity of $5.0 \mathrm{dm}^{3}$ containing Dystroferric Red Latosol of clayey texture, which was collected from a fallow area from a depth of 80 to $100 \mathrm{~cm}$.

The experimental design adopted was completely randomized, arranged in a factorial scheme of $4 \times 4$, with four replicates. The factors were constituted of the control treatment (without $\mathrm{Al}$ application) and three aluminum levels in the soil (8.2, 16.5, and $24.0 \mathrm{mmol}_{\mathrm{c}} \mathrm{dm}^{-3}$ ) and four provenances of $J$. curcas seeds $(\mathrm{P} 1=$ Dourados-MS; P2 = Montes Claros-MG; P3 = Alta Floresta-MT; and $\mathrm{P} 4=$ Petrolina-PE). Aluminum levels were chosen based on pre-tests.

Plant growth (humates) was assessed for the four levels of aluminum in the soil and the four provenances of Jatropha; the effects were investigated at 25, 50,75, and 100 days after emergence. Three repetitions were set for each treatment, and 192 vessels were used in total.

The different levels of aluminum in the soil were prepared from the parent soil (Al 1), which had an aluminum level of $24.0 \mathrm{mmol}_{\mathrm{c}} \cdot \mathrm{dm}^{-3}$. The parent soil was treated with limestone "filler" to increase the soil base saturation to $33.3 \%(\mathrm{Al} 2), 56.6 \%$ (Al 3 ), and $80 \%$ ( $\mathrm{Al} \mathrm{4}$ ), for which the limestone doses corresponded to $0.48,0.97$, and $1.65 \mathrm{~g} \cdot \mathrm{kg}^{-1}$, respectively. At the end of the incubation of soil samples, Al 2, Al 3, and Al 4 were subjected to chemical analysis (Table 1); the levels of aluminum in these samples was $16.5,8.2$, and $0.0 \mathrm{mmol}_{\mathrm{c}} \cdot \mathrm{dm}^{-3}$, respectively. Soil samples Al 1-Al4were used in the experimental plots. The level of aluminum was quantified using $1 \mathrm{M} \quad \mathrm{KCl}$ extractor and bromothymol blue indicator and titration with 0.025 $\mathrm{M} \mathrm{NaOH}$. The soil was fertilized as recommended by Novais, Neves and Barros (1991) for growing plants in controlled environments.

The four provenances were seeded immediately after soil fertilization; eight seeds per pot were seeded at a depth of $3 \mathrm{~cm}$. The vessels were watered up to $80 \%$ of the water-holding capacity, and the number of emerged seedlings was assessed daily until the $12^{\text {th }}$ day after sowing when seedling emergence stabilized across all treatments. Seedling emergence percentage (E \%), emergence speed index (ESI), and mean emergence time (MET) were recorded.

During the evaluation of plant growth, thinning was performed, and two plants per pot were retained. Every 25 days post-emergence (25, 50,75 , and 100 days), the data for the following characteristics were collected:

Plant height was used a ruler graduated in centimeters $(\mathrm{cm})$; Leaf area was measured using an LI-COR $^{\circledR}$; Chlorophyll index was obtained using a Konica Minolta, SPAD 502 chlorophyll analyzer; photosynthetic rate $\left(A \mu \mathrm{mol} \mathrm{m}^{-2} \mathrm{~s}^{-1}\right)$, foliar

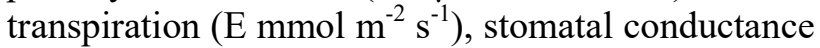
$\left(g s \mathrm{~mol} \mathrm{~m} \mathrm{~m}^{-1}\right)$ and internal $\mathrm{CO}_{2}$ levels $(C i \mu \mathrm{mol}$ $\mathrm{mol}^{-1}$ ) were measured using an infrared gas analyzer (IRGA) (Model LCi PRO; Analytical Development Co. Ltd., Hoddesdon, UK). The measurements were performed on three seedlings per treatment in the morning, between 08:00 $\mathrm{h}$ and 11:00 $\mathrm{h}$, and were recorded from two fully extended previously marked leaves. All measurements were taken from these marked leaves. Only the data measured under a photosynthetic photon flux (PPF) above $700 \mathrm{mmol}$ $\mathrm{m}^{-2} \mathrm{~s}^{-1}$ were considered.

Chlorophyll $a$ fluorescence was measured for fully expanded leaves located on intermediate stem branches by using the portable fluorometer model OS-30p (Opti-Sciences Chlorophyll Fluorometer), Hudson, USA). The initial (F0), maximum $(\mathrm{Fm})$, and variable fluorescence $(\mathrm{Fv}=$ Fm-F0) determined between 08:00 and 11:00 $\mathrm{h}$ in the morning; before the analysis, the leaves were subjected to a 30 -min period of adaptation to dark 
by using adapters and clips for all reaction centers under foliar condition of "open," i.e., when complete oxidation of the photosynthetic electron transport system was noted.

Table 1. Values for chemical analysis and soil particle size (Al 1) and after the correction to bases saturation $33.3(\mathrm{Al} 2), 56.6(\mathrm{Al} \mathrm{3})$ and $80 \%(\mathrm{Al} 4)$.

\begin{tabular}{|c|c|c|c|c|}
\hline $\begin{array}{l}\text { Chemical } \\
\text { Characteristic }\end{array}$ & Al 1 & $\mathrm{Al} 2$ & Al 3 & $\mathrm{Al} 4$ \\
\hline $\mathrm{Al}\left(\mathrm{mmol}_{\mathrm{c}} \mathrm{dm}^{-3}\right)^{1}$ & 24.00 & 16.50 & 8.20 & 0.00 \\
\hline $\mathrm{m} \%$ & 82.64 & 41.56 & 17.75 & 0.00 \\
\hline $\mathrm{pH} \mathrm{CaCl}{ }_{2}$ & 4.20 & 4.71 & 5.04 & 5.37 \\
\hline $\mathrm{pH}$ water & 4.83 & 5.03 & 5.36 & 5.72 \\
\hline O.M. $\left(\mathrm{g} \mathrm{dm}^{3}\right)$ & 6.30 & 6.30 & 6.30 & 6.30 \\
\hline $\mathrm{P}\left(\mathrm{mg} \mathrm{dm}^{-3}\right)$ & 0.25 & 32.52 & 58.20 & 72.43 \\
\hline $\mathrm{K}\left(\mathrm{mmol}_{\mathrm{c}} \mathrm{dm}^{-3}\right)$ & 0.31 & 5.1 & 9.1 & 7.8 \\
\hline $\mathrm{Ca}\left(\mathrm{mmol}_{\mathrm{c}} \mathrm{dm}^{-3}\right)$ & 3.4 & 13.5 & 19.8 & 26.2 \\
\hline $\operatorname{Mg}\left(\mathrm{mmol}_{\mathrm{c}} \mathrm{dm}^{-3}\right)$ & 1.3 & 4.6 & 9.1 & 1.38 \\
\hline $\mathrm{H}+\mathrm{Al}\left(\mathrm{mmol}_{\mathrm{c}} \mathrm{dm}^{-3}\right)$ & 44.8 & 36.0 & 27.0 & 20.0 \\
\hline $\mathrm{SB}\left(\mathrm{mmol}_{\mathrm{c}} \mathrm{dm}^{-3}\right)$ & 5.0 & 23.2 & 38.0 & 47.8 \\
\hline $\mathrm{CTC}\left(\mathrm{mmol}_{\mathrm{c}} \mathrm{dm}^{-3}\right)$ & 49.9 & 59.2 & 65.0 & 67.8 \\
\hline $\mathrm{V} \%$ & 10.11 & 39.19 & 58.45 & 70.50 \\
\hline GranulometricCharacteristic & Values & & & \\
\hline Clay $(\%)$ & 69.50 & & & \\
\hline Silt (\%) & 23.02 & & & \\
\hline Sand $(\%)$ & 7.48 & & & \\
\hline
\end{tabular}

The experiment involved a completely randomized design, as the treatments were arranged in main plots, and the plot scheme included four levels of aluminum in the soil $(0.0,8.2,16.5$, and $\left.24.0 \mathrm{mmol}_{\mathrm{c}} \mathrm{dm}^{-3}\right)$. The sub parcels were planted with four provenances of $J$. curcas to represent four towns in different regions of Brazil (P1, P2, P3, P4), and the sub parcels represented the four seasons $(25$, 50,75 , and 100 days post-emergence). Data were analyzed using analysis of variance $F$-test at the $5 \%$ probability, and statistically significant effect of the averages of the provenances were compared using theTukey test. The averages of levels of aluminum and the interactions between the factors were adjusted using regression analysis at 5\% level of probability.

\section{RESULTS}

The seedling emergence percentage, ESI and MET were not significantly different across the four provenances and among the aluminum levels evaluated (Table 2). There was no significant effect on any of the interaction traits evaluated. The average percentage of emergence was high $(88 \%)$; the average ESI, and MET were 3.72 and was 8.94 days, respectively.
Plants of P1 showed greater height in the absence of aluminum, and those of P4 showed greater height even in the presence of high level of aluminum (Figure 1A). Even 35 days after emergence, the height of control plants was higher than that of plants grown in the presence of 8.2 $\mathrm{mmol}_{\mathrm{c}} \cdot \mathrm{dm}^{-3}$ aluminum; however, after this period the values were higher in the soil without aluminum and remained the highest until 100 days after emergence (Figure 1B), signaling the stressful effect of aluminum on shoot growth.

Plants of origin P3 showed the greatest leaf area even when the level of aluminum in the soil was $7.8 \mathrm{mmol}_{\mathrm{c}} \cdot \mathrm{dm}^{-3}$; above this level, the plants of origin $\mathrm{P} 4$ and $\mathrm{P} 2$ showed the best growth compared to those of the remaining provenances (Figure 1C). Analysis of the effect of aluminum on the leaf area over time suggested the presence of a linear response, with the highest values in plants treated with $0 \mathrm{mmol}_{\mathrm{c}} \cdot \mathrm{dm}^{-3} \mathrm{Al}$ (Figure $1 \mathrm{D}$ ); further, $\mathrm{P} 4$ and P3 showed greater average leaf area with no significant differences between the two (Figure 1E), suggesting different behavior of provenances in the presence of aluminum. 
Table 2. Analysis of variance for emergency (E), emergence speed index (ESI) and mean emergence time (MET), plant height (PH), leaf area (LA), chlorophyll (C) in function of different levels of aluminum in the soil (Al), provenances (P) of Jatropha curcas L. seed and time (T).

\begin{tabular}{lllllll}
\multirow{2}{*}{ Source of Variation } & \multicolumn{7}{l}{ Medium Squares } & & \\
\cline { 2 - 6 } & E & ESI & MET & PH & LA & CI \\
\hline Al & $1.16^{\text {ns }}$ & $0.05^{\text {ns }}$ & $1.85^{\text {ns }}$ & $638.4^{* *}$ & $736168.8^{* *}$ & $309.0^{* *}$ \\
P & $8.27^{\text {ns }}$ & $0.15^{\text {ns }}$ & $0.84^{\text {ns }}$ & $11.3^{\text {ns }}$ & $121077.1^{* *}$ & $67.4^{*}$ \\
Al x P & $7.85^{\text {ns }}$ & $0.10^{\text {ns }}$ & $0.30^{\text {ns }}$ & $19.0^{*}$ & $177781.8^{* *}$ & $21.7^{*}$ \\
T & - & - & - & $1313.3^{* *}$ & $5324288.3^{* *}$ & $3831.9^{* *}$ \\
Al x T & - & - & - & $89.9^{* *}$ & $106694.9^{* *}$ & $46.7^{* *}$ \\
P x T & - & - & - & $6.2^{\text {ns }}$ & $23242.5^{* *}$ & $16.0^{\text {ns }}$ \\
Al x P x T & - & - & - & $8.0^{\text {ns }}$ & $25702.2^{\text {ns }}$ & $19.6^{\text {ns }}$ \\
\hline Average & 87.6 & 3.7 & 8.9 & 21.8 & 548.6 & 33.4 \\
\hline
\end{tabular}

** Significant effect the $1 \%$ probability for the F-test; * Significant effect the $5 \%$ probability for the F-test; ${ }^{\text {ns }}$ non-significant.

A)

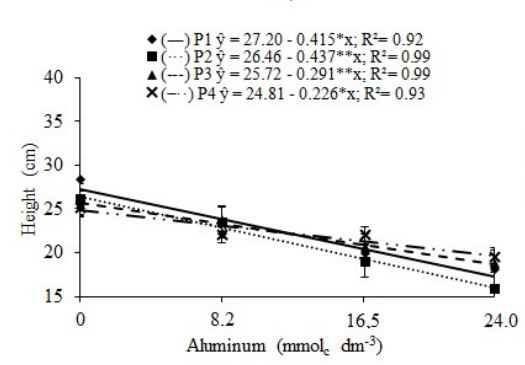

C)

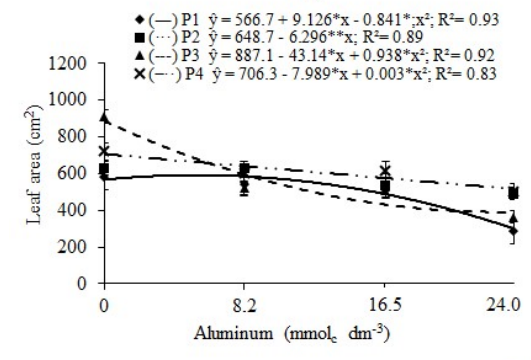

B)

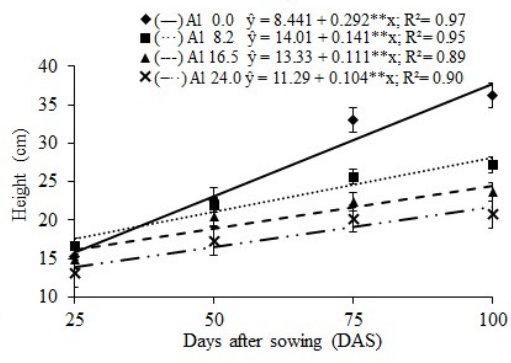

D)

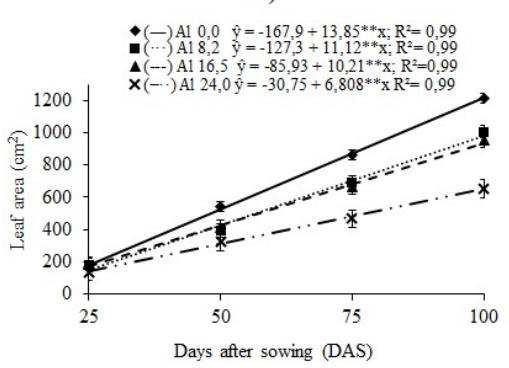

E)

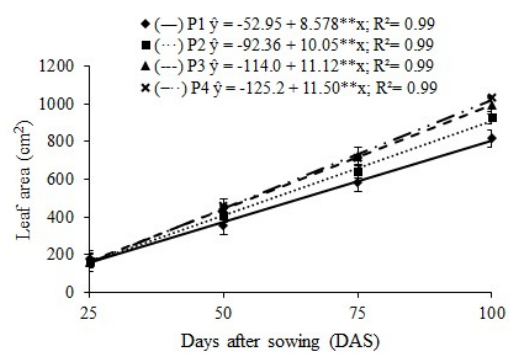

Figure 1. Height (A, B) and leaf area (C, D, E) of plants Jatropha curcas $\mathrm{L}$. in function of different levels of aluminum in the soil $\left(8.2,16.5,24.0 \mathrm{mmol}_{\mathrm{c}} \mathrm{dm}^{-3}\right.$ and control), provenances of the seeds $(\mathrm{P} 1=$ Dourados-MS; P2 = Montes Claros-MG; P3 = Alta Floresta-MT; P4 = Petrolina-PE) and days after emergence $(25,50,75$ and 100$)$.

The chlorophyll content of the P4 plants was higher at high levels of aluminum, showing the maximum value of 35.5 at aluminum levels of 8.2 $\mathrm{mmol}_{\mathrm{c}} \cdot \mathrm{dm}^{-3}$ (Figure 2A). For the plants of P1 and P3 provenances, chlorophyll content reduced with increasing levels of aluminum. With time, the adverse effect of aluminum on chlorophyll index increased, with more pronounced effect at 16.5 and $24.0 \mathrm{mmol}_{\mathrm{c}} \cdot \mathrm{dm}^{-3}$ of aluminum in the soil (Figure $2 \mathrm{~B})$; these treatments caused yellowing of the young leaves of $J$. curcas (25 DAS) which was overcome with the growth of the plant. 
A)

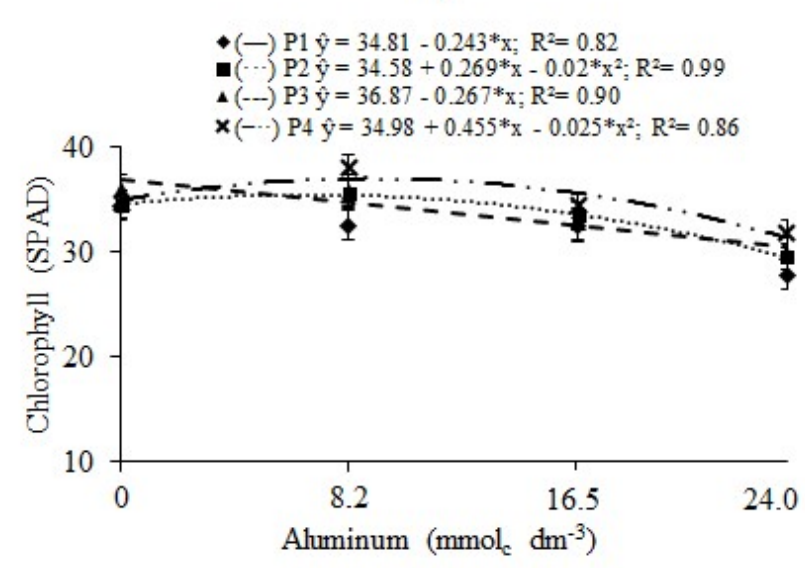

C)

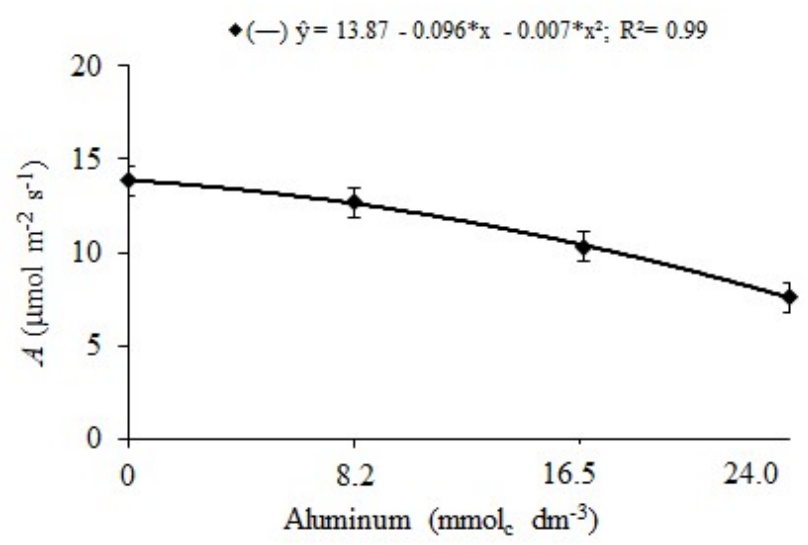

B)

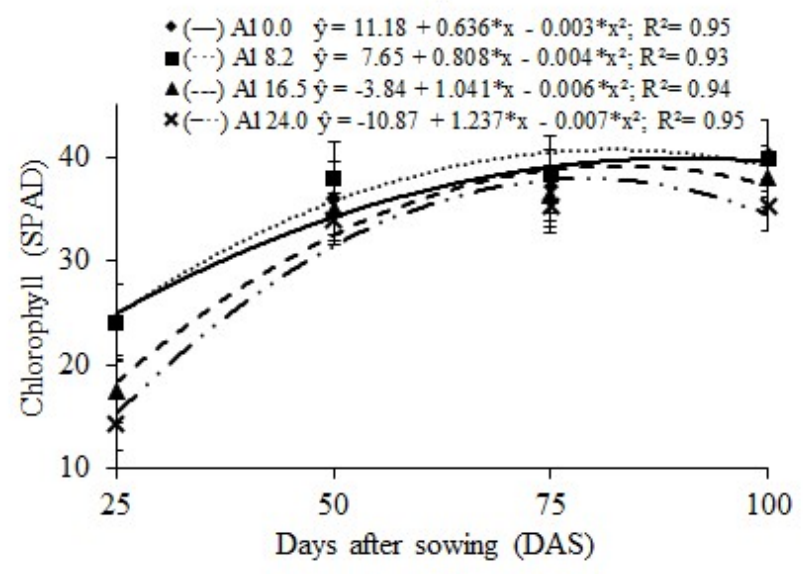

D)

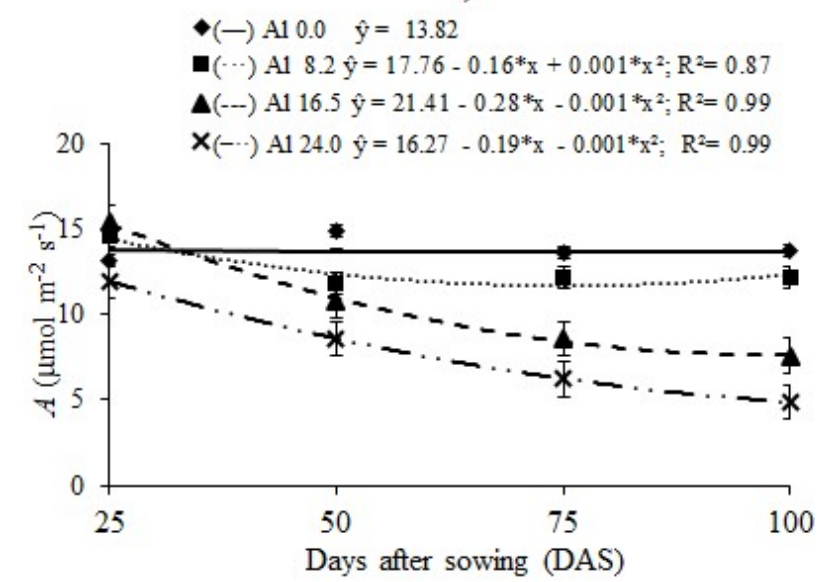

Figure 2. Chlorophyll (SPAD) (A, B) and photosynthetic rate $(A)(\mathrm{C}, \mathrm{D})$ of plants Jatropha curcas L. in function of different levels of aluminum in the soil $\left(8.2,16.5,24.0 \mathrm{mmol}_{\mathrm{c}} \mathrm{dm}^{-3}\right.$ and control), provenances of the seeds $(\mathrm{P} 1=$ Dourados-MS; P2 = Montes Claros-MG; P3 = Alta Floresta-MT; P4 $=$ Petrolina-PE) and days after emergence $(25,50,75$ and 100$)$.

The aluminum effect was observed for all the features of the photosynthetic metabolism evaluated; however, the effect of the origins and provenances interaction and aluminum was observed only for the stomatal conductance and the interactions between the other treatments varied for other characteristics (Table 3 ).

Table 3. Analysis of variance for photosynthetic rate $(A)$, foliar transpiration (E), stomatal conductance ( $g s)$, internal $\mathrm{CO}_{2}$ concentration $(\mathrm{Ci})$, initial fluorescence $(\mathrm{FO})$, maximum fluorescence $(F m)$ and variable fluorescence $(F v)$ in function of different levels of aluminum in the soil $(\mathrm{Al})$, provenances $(\mathrm{P})$ of Jatropha curcas L. seed and time (T).

\begin{tabular}{|c|c|c|c|c|c|c|c|}
\hline \multirow{2}{*}{ Source of Variation } & \multicolumn{7}{|c|}{ Medium Squares } \\
\hline & $\bar{A}$ & $E$ & Gs & $\mathrm{Ci}$ & $F 0$ & $F v$ & $F m$ \\
\hline $\mathrm{Al}$ & $370.6^{* *}$ & $241.5^{* *}$ & $2.02 *$ & $7417.17 * *$ & $615.55^{*}$ & $8012.98 * *$ & $4993.71 *$ \\
\hline $\mathrm{P}$ & $9.9^{\text {ns }}$ & $7.7^{\mathrm{ns}}$ & $0.35^{*}$ & $925.78^{\mathrm{ns}}$ & $248.56^{\mathrm{ns}}$ & $3088.79^{\text {ns }}$ & $4946.47^{\mathrm{ns}}$ \\
\hline $\mathrm{Al} \times \mathrm{P}$ & $18.9^{\mathrm{ns}}$ & $8.863^{\text {ns }}$ & $0.27^{*}$ & $1005.65^{\mathrm{ns}}$ & $129.65^{\text {ns }}$ & $1080.35^{\text {ns }}$ & $977.89^{\text {ns }}$ \\
\hline $\mathrm{T}$ & $187.9^{* *}$ & $66.51 * *$ & $0.34 * *$ & $8302.02 * *$ & $687.79 *$ & $5663.24 * *$ & $6989.90 * *$ \\
\hline $\mathrm{Al} \times \mathrm{T}$ & $45.8 * *$ & $40.96 * *$ & $0.38 * *$ & $2109.01^{\mathrm{ns}}$ & $84.31^{\mathrm{ns}}$ & $975.31^{\mathrm{ns}}$ & $1335.53^{\mathrm{ns}}$ \\
\hline $\mathrm{P} \times \mathrm{T}$ & $4.2^{\mathrm{ns}}$ & $5.19^{\mathrm{ns}}$ & $0.11^{\mathrm{ns}}$ & $940.14^{\mathrm{ns}}$ & $105.45^{\text {ns }}$ & $589.47^{\mathrm{ns}}$ & $692.71^{\mathrm{ns}}$ \\
\hline $\mathrm{Al} \times \mathrm{P} \times \mathrm{T}$ & $6.7^{\mathrm{ns}}$ & $2.80^{*}$ & $0.068^{\mathrm{ns}}$ & $591.52 *$ & $76.42^{\mathrm{ns}}$ & $649.79^{\text {ns }}$ & $858.52^{\mathrm{ns}}$ \\
\hline Average & 11.1 & 9.76 & 0.47 & 247.71 & 62.87 & 223.84 & 286.71 \\
\hline
\end{tabular}

** Significant effect the $1 \%$ probability for the F-test; * Significant effect the $5 \%$ probability for the F-test; ${ }^{\text {ns }}$ non-significant. 
With respect to gas exchange, the photosynthetic rate $(A)$ of plants reduced significantly with increasing aluminum levels in the soil, regardless of the origin of the seeds (Figure 2 C). Control plants (without aluminum) showed no significant difference in the photosynthetic rate during the evaluation period and showed higher photosynthetic rates from 30 days after emergence than those of plants of the other treatments (Figure 2D) which can be attributed to the presence of aluminum in the other treatments.

Similarly, the transpiration rate $(E)$ reduced with increasing aluminum levels in the soil (Figure 3A) but increased with the age of plants.
A)
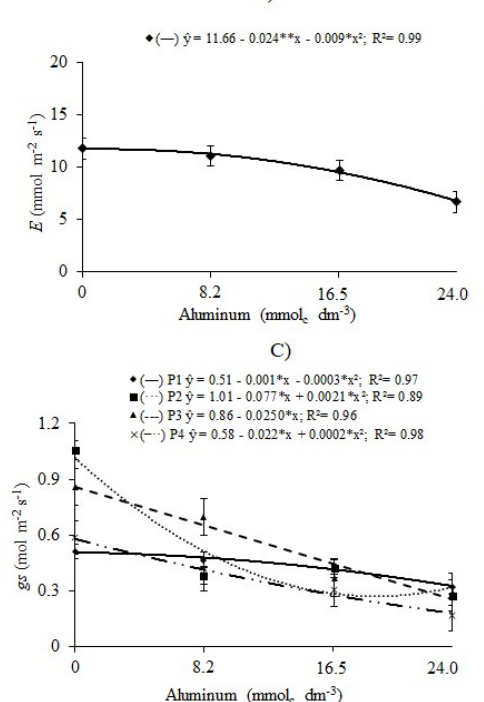

E)

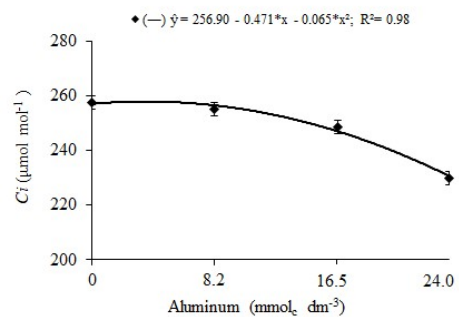

B)

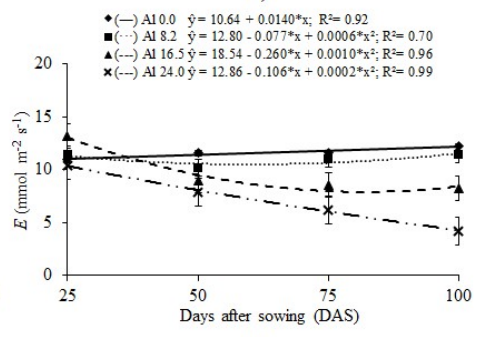

D)

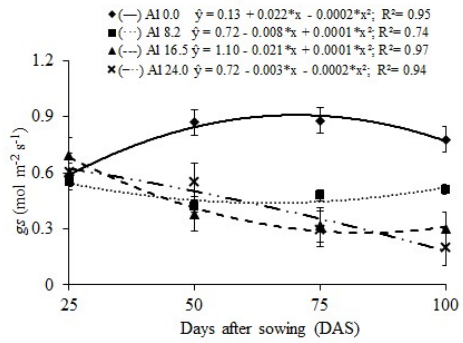

F)

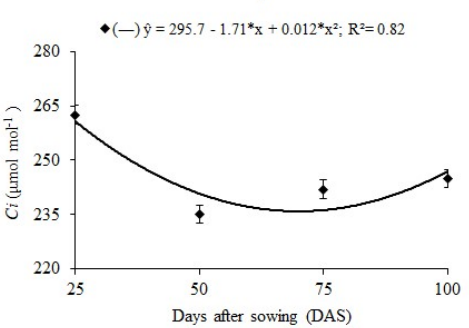

Figure 3. Foliar transpiration $(E)(A, B)$, stomatal conductance $(g s)(\mathrm{C}, \mathrm{D})$, internal $\mathrm{CO}_{2}$ concentration $(C i)(\mathrm{E}$, F) of plants Jatropha curcas L. in function of different levels of aluminum in the soil $(8.2,16.5$, $24.0 \mathrm{mmol}_{\mathrm{c}} \mathrm{dm}^{-3}$ and control), provenances of the seeds $(\mathrm{P} 1=$ Dourados-MS; P2 $=$ Montes ClarosMG; P3 = Alta Floresta-MT; P4 = Petrolina-PE) and days after emergence (25, 50, 75 and 100).

The treatment with 16.5 and 24.0 $\mathrm{mmol}_{\mathrm{c}} \cdot \mathrm{dm}^{-3}$ aluminum caused a significant reduction in transpiration with time (Figure 3B). The stomatal conductance ( $g s)$ also reduced with increasing aluminum levels (Figure 3C), and the plants treated with $0 \mathrm{mmol}_{\mathrm{c}} \cdot \mathrm{dm}^{-3}$ aluminum showed better stomatal conductance than those of $\mathrm{P} 2$ plants. The $g s$ and $A$ were similar and transpiration was higher in the absence of aluminum from 30 days after emergence (Figure 3D), suggesting the stressful effect of aluminum on the gas exchange of J. curcas.

The internal $\mathrm{CO}_{2}$ concentration $(\mathrm{Ci})$ did not show significant interaction for the factors analyzed
(Table 3). At levels greater than $6.0 \mathrm{mmol}_{\mathrm{c}} \cdot \mathrm{dm}^{-3}$ aluminum, the $C i$ of the concentration reduced (Figure 3E). The $C i$ continued to decrease significantly up to 70 days after emergence and reached the minimum value of $238 \mu \mathrm{mol} \cdot \mathrm{mol}^{-1}$, but increased thereafter (Figure $3 \mathrm{~F}$ ).

The $F 0$ had no significant interaction with the studied factors (Table 3); however, the fluorescence increased linearly as the levels of aluminum in the soil increased (Figure 4A). Thus, FO reduced over the course of evaluation (Figure 4B), emphasizing the stressful effect of aluminum on plants in the early stages of development, but this effect was mitigated with plant growth. 
A)

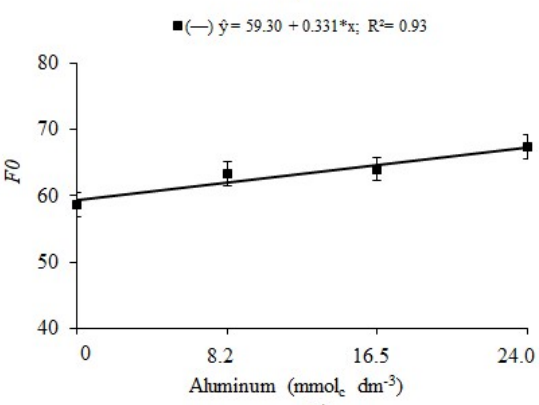

C)

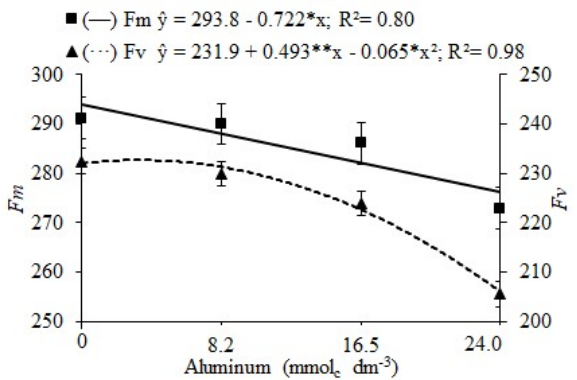

B)

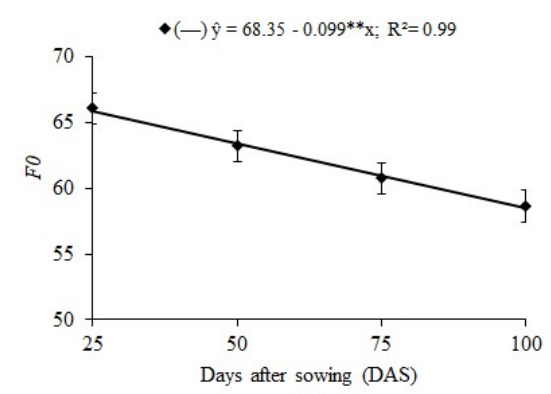

D)

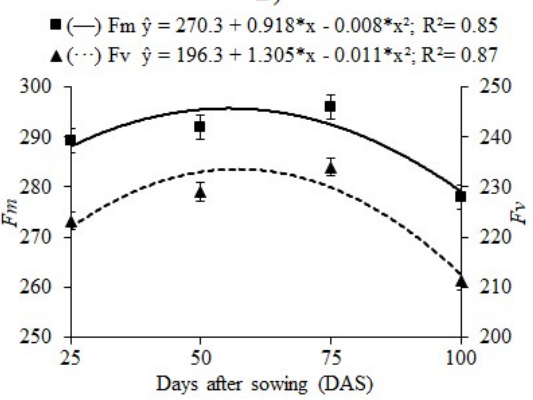

Figure 4. Initial fluorescence $(F 0)(\mathrm{A}, \mathrm{B})$, maximum fluorescence $(F m)$ and variable fluorescence $(F v)(\mathrm{C}, \mathrm{D})$ of plants Jatropha curcas L. in function of different levels of aluminum in the soil $(8.2,16.5 ; 24.0$ $\mathrm{mmol}_{\mathrm{c}} \mathrm{dm}^{-3}$ and control), provenances of the seeds (P1 = Dourados-MS; P2 = Montes Claros-MG; P3 $=$ Alta Floresta-MT; P4 $=$ Petrolina-PE) and days after emergence $(25,50,75$ and 100$)$.

There was no significant effect $(p>0.05)$ for the interaction between the levels of aluminum, seed origins, and age of plants and fluorescence and maximum fluorescence characteristics. However, $F v$ levels reduced after treatment with more than 6.0 $\mathrm{mmol}_{\mathrm{c}} \mathrm{dm}^{-3}$ aluminum (Figure 4C). Regression analysis with respect to time showed that the best-fit quadratic model was for the data of $F v$, and the maximum value was observed at 60 days after emergence (Figure 4D). The $\mathrm{Fm}$ reduced with an increasing level of aluminum in the soil (Figure 4C) and the maximum value was noted at 60 days after emergence (Figure 4D).

\section{DISCUSSION}

The aluminum levels and sources did not adversely affect the physiological potential of the seeds, as revealed by the germination rates, however, reduced the growth of the aerial part and gas exchange, impairing the operation of photosynthetic apparatus.

Different results have been previously reported for $J$. curcas, which could be attributed to the genetic variability of this species. For example, the emergence level and speed of the seedlings were reduced when levels above $10 \mathrm{mmol} \cdot \mathrm{L}^{-1} \mathrm{Al}$ were present in the soil, and the emergence of seedlings was of $98 \%$ at a level of $20 \mathrm{mmol} \cdot \mathrm{L}^{-1} \mathrm{Al}$ (GORDIN et al., 2013).
The height of the plants reduced with increasing aluminum levels in the soil. This could be attributed to the limitation on nutrient absorption by plants when $\mathrm{Al}$ was present in the soil at toxic levels. The main symptom of Al toxicity in differents plants was rapid root growth inhibition caused by different mechanisms, such as interactions of $\mathrm{Al}^{3+}$ with the cell wall and plasma membrane, callose production, and damage to the apoplast (MA et al., 2004, BATISTA et al., 2013).

$J$. crurcas plants to be compared to the witness, showed $26 \%$ reduction in the length of the shoot when grown with irrigation water containing $20 \mathrm{mmol} \mathrm{L}^{-1}$, with values ranged from other levels tested $\left(5,10: 15 \mathrm{mmol} \mathrm{L}^{-1}\right)$. The leaf area was only possible be evaluated in plants irrigated with $5 \mathrm{mmol}$ $\mathrm{L}^{-1}$ and not varied among plants witness; in higher levels, plants presented symptoms of toxicity in the air, as the winding foliar edges, chlorosis, necrosis and death of some plants (GORDIN et al., 2013). Similar results from reduced height growth and dimming characteristic of aluminum toxicity to the same species were observed by Macedo et al. (2011).

The results obtained for leaf area were similar to those observed for Ricinus communis by Lima et al. (2007), in which the leaf area of plants grown in soils with aluminum levels ranging between 0 and $2.4 \mathrm{cmol}_{\mathrm{c}} \cdot \mathrm{dm}^{-3}$ reduced by $77 \%$. They suggested that the reduced root growth 
reduces the volume of soil explored by the roots, hindering the uptake of water and nutrient sand compromising the formation of shoot organs, especially leaves, and eventually reducing plant productivity.

The reduction of chlorophyll content of $J$. curcas suggests that $\mathrm{Al}$ cause toxicity in leaves, in many cases destroying the chloroplast and resulting in decreased chlorophyll content (YANG et al., 2015). The results were similar to that observed for aluminum-sensitive potato clones, which showed levels exceeding $100 \mathrm{mg} \cdot \mathrm{L}^{-1}$; however, the tolerant genotype showed increased chlorophyll in the range close to 100 and $150 \mathrm{mg} \cdot \mathrm{L}^{-1}$ (TABALDI et al., 2007).

Prolonged exposure of plants or organelles to stressed conditions can result in photo-destruction of photosynthetic pigments, a phenomenon usually referred to as photooxidation, resulting in the reduction of pigment concentration and leading to cell or organism death (ARAUJO; DEMINICIS, 2009). This oxidative damage probably inhibits the activity of aminolevulinic dehydratase acid, an important enzyme in the biosynthesis of chlorophyll (PEREIRA et al., 2006).

Similar results were observed in the literature under stressful conditions caused by $J$. curcas irrigation with saline water, which also provided reduced photosynthesis and reduced growth (SHAH et al., 2012).

Transpiration and stomatal conductance were reduced with increasing aluminum levels in the soil; these results suggest that stress induced by aluminum affects the photosynthetic activity of plants via both stomatal and non-stomatal effects (ARAUJO et al., 2010). Similar results were observed in eucalypt clones grown in nutrient solution with four different treatment of acid and aluminum (YANG et al., 2015). Thus, we believe that the lowest mean values of stomatal conductance with increasing levels of aluminum can reflect the closing of stomata, which consequently reduces the rate of sweating and is directly related to the stomatal conductance and photosynthesis (MARIANO et al., 2009).

The highest levels of aluminum causing reduction in root system development of $J$. curcas (data not presented) reduced the hydration level of plants, which is reflected as reduced transpiration rate and stomatal conductance. Therefore, reduction in sweating would be a strategy that plants use to restrict water (BUCCI et al., 2008) to overcome the effects of poor growth of the root system.

The results for $\mathrm{Ci}$ suggested that the decrease in photosynthetic rate was caused by the reduction of stomatal conductance. In studies performed using Citrus limonia (PEREIRA et al., 2000), and Triticum aestivum L. (MOUSTAKA; OUZOUNIDOU; LANNOYER, 1996), the decrease in photosynthetic rate was reported to occur due to factors related with stomatal conductance and photosynthetic metabolism.

The increase in fluorescence revealed by $F O$ corresponded to the point when quinone (primary FSII electron receiver) was totally oxidized and the FSII reaction center was open, which is an imminent situation for the activation of photochemical reactions. This increase of $F 0$, which was independent of the photochemical events reflects the destruction of reaction center FSII or decrease in energy transfer capability the exciting antenna to the reaction center (BAKER; ROSENQVST, 2004).

Maximum fluorescence reductions depending on the increased levels of aluminum in the soil are characterized by the photoreduction deficiency of the quinone electron acceptor, which is the main target of photosystem II, and is responsible for the continuity of the chain flow between the existing photosystems; therefore, under these conditions of photoreduction deficiency of quinone, the flow of electrons between photosystems is directly affected (SILVA et al., 2006) resulting in low photosynthesis rates because of decreased enzyme activity, and thus causing low energy rates. The $F m$ is noted when virtually all quinone is reduced and the reaction centers are unable to activate photochemical reactions and have reached their maximum capacity (BAKER; ROSENQVST, 2004).

The results observed in this study confirm information observed in the review of Gordin et al. (2013) which suggests that the correction of the acidity and fertility of the soil is crucial for success and profitability in this culture, requiring the completion of setting. These authors concluded that toxic effects of aluminum on the growth of the plants of $J$. curcas are perceived from the levels of 5 mmol $\mathrm{L}^{-1}$, behavior that corroborates the results observed in this work for growth and metabolism photosynthetic.

\section{CONCLUSIONS}

The provenances and aluminum levels did not affect the emergence and vigor of $J$. curcas seeds.

Gas exchanges were affected negatively by aluminum and the responses of the chlorophyll a fluorescence indicate harmful effect in the photosynthetic apparatus. 
The seeds of provenance P4 (Petrolina-PE)

has lower sensitivity to aluminum.

RESUMO: $O$ alumínio em níveis elevados no solo afeta a emergência, o crescimento e o desenvolvimento de diversas espécies. Diante disso, o objetivo desse trabalho foi avaliar a emergência e o comportamento fisiológico de quatro procedências de Jatropha curcas submetidas a diferentes níveis de alumínio. O experimento foi conduzido em casa de vegetação, em delineamento inteiramente casualizado, com quatro níveis de alumínio no solo $\left(8,2 ; 16,5\right.$ e $24,0 \mathrm{mmol}_{\mathrm{c}} \mathrm{dm}^{-3}$ e o controle) e quatro procedências de sementes de $J$. curcas $(\mathrm{P} 1$ = Dourados-MS P2 = Montes Claros-MG, P3 = Alta Floresta-MT e P4 = Petrolina-PE), e os efeitos da toxicidade do alumínio foram investigados aos 25, 50, 75 e 100 dias após a emergência. A emergência das plântulas não foi afetada pelo tratamento com alumínio; no entanto, a altura e a área foliar de P1, P2 e P3 foram reduzidas com níveis crescentes de alumínio. A emergência e o vigor das plântulas das procedências não foram afetados pelos níveis de alumínio avaliados. A taxa fotossintética, taxa de transpiração e condutância estomática também foram reduzidas quando as plantas foram cultivadas em solo contendo altas níveis de alumínio. As plantas P4 foram menos sensíveis aos níveis crescentes de alumínio.

PALAVRAS-CHAVE: Jatropha curcas L. Oleaginosa. Trocas gasosas. Toxicidade.

\section{REFERENCES}

ARAUJO, S. A. C.; DEMINICIS, B. B. Fotoinibição da Fotossíntese. Revista Brasileira de Biociências, Porto Alegre, v. 7, n. 4, p. 463-472, 2009. http://www.ufrgs.br/seerbio/ojs/index.php/rbb/article/view/1009

ARAUJO, S. A. C.; VASQUEZ, H. M.; CAMPOSTRINI, E.; NETTO, A. T.; DEMINICES, B. B.; LIMA, E. S. Características fotossintéticas de genótipos de capim elefante anão em estresse hídrico. Acta Scientiarum, Maringá, v. 32, n. 1, p. 1-7, 2010. http://dx.doi.org/10.4025/actascianimsci.v32i1.8961

BAKER, N. R.; ROSENQVST, E. Applications of chlorophyll fluorescence can improve crop production strategies: an examination of future possibilities. Journal of Experimental Botany, Oxford, v. 55, p. 16071621, 2004. https://doi.org/10.1093/jxb/erh196

BATISTA, M. F.; MOSCHETA, I. S.; BONATO, C. M.; BATISTA, M. A.; ALMEIDA, O. J. G; INOUE, T.T. Aluminum in corn plants: influence on growth and morpho-anatomy of root and leaf. Revista Brasileira de Ciência do Solo, v. 37, p.177-187, 2013. https://repositorio.unesp.br/bitstream/handle/11449/20294/S010006832013000100018

BUCCI, S. J.; SCHOLZ, F. G.; GOLDSTEIN, G.; MEINZER, F. D.; FRANCO, A. C.; ZHANG, Y.; HAO, G. Water relations and hydraulic architecture in Cerrado trees: adjustments to seasonal changes in water availability and evaporative demand. Journal of Plant Physiology, v. 20, n. 3, p. 233-245, 2008. http://dx.doi.org/10.1590/S1677-04202008000300007

CAMEJO, D.; RODRIGUEZ, P.; MORALES, M. A.; AMICO, J. M. D.; TORRECILlAS, A. ALARCON, J. J. High temperature effects on photosynthetic activity of two tomato cultivars with different heat susceptibility. Journal of Plant Physiology, v. 162, p. 281-289, 2005. https://www.ncbi.nlm.nih.gov/pubmed/15832680 https://doi.org/10.1016/j.jplph.2004.07.014

DIVAKARA, B. N.; UPADHYAYA, H. D.; WANI, S. P.; GOWDA LAXMIPATHI, C. L. Biology and genetic improvement of Jatropha curcas L.: A review. Applied Energy, v. 87, p. 732-742, 2010. https://doi.org/10.1016/j.apenergy.2009.07.013 
DURÃES, F. O. M.; MAGALHÃES, P. C.; GAMA, E. E. G.; OLIVEIRA, A. C. Caracterização fenotípica de linhagens de milho quanto ao rendimento e à eficiência fotossintética. Revista Brasileira de Milho e Sorgo, Sete Lagoas, v. 4, n. 3, p 355-361, 2005. https://doi.org/10.18512/1980-6477/rbms.v4n3p355-361

GORDIN, C. R. B.; MARQUES, R. F.; ROSA, R. J. M.; SANTOS, A. M.; SCALON, S. P. Q. Emergência de plântulas e crescimento inicial do pinhão manso exposto a alumínio. Semina: Ciências Agrárias, Londrina,v. 34 , n. 1, p. 147-156, 2013. DOI: 10.5433/1679-0359.2013v34n1p147

LAVIOLA, B. G.; ROSADO, T. B.; BHERING, L. L.; KOBAYASHI, A. K.; RESENDE, M. D. V. Genetic parameters and variability in physic nut accessions during early developmental stages. Pesquisa Agropecuária Brasileira, Brasília, v. 45, p.1117-1123, 2010. http://dx.doi.org/10.1590/S0100-204X2010001000010

LIMA, R. L. S.; SEVERINO, L. S.; FERREIRA, G. B.; SILVA, M. I. L.; ALBUQUERQUE, R. C.; BELTRÃO, N. E. M. Crescimento da mamoneira em solo com alto teor de alumínio na presença e ausência de material orgânica. Revista de Oleaginosas e Fibrosas, Campina Grande, v. 11, n. 1, p. 15-21, 2007. $\mathrm{http} / /$ www.agencia.cnptia.embrapa.br/Repositorio/Crescimento $+\mathrm{da}+$ mamoneira+em+solo+com+alto+teor+de+ aluminio + na + presenca+e+ausencia + de + materia+organica_000h4u $7 \mathrm{e} 9 \mathrm{vn} 02 \mathrm{wx} 7 \mathrm{ha} 0 \mathrm{awymtyv} 67 \mathrm{mai}$.pdf

MA, J. F..; SHEN, R.; NAGAO, S.; TANIMOTO, E. Aluminum targets elongating cells by reducing cell wall extensibility in wheat roots. Plantand Cell Physiology, v. 45, n. 5, p. 583-589, 2004. http://dx.doi. org/10.1093/pcp/pch060

MACEDO, F. L.; PEDRA, W. N.; SILVA, S. A.; BARRETO, M. C. V.; MANN, R. S. Efeito do alumínio em plantas de Pinhão-manso (Jatropha curcas L.), cultivadas em solução nutritiva. Semina: Ciências Agrárias, Londrina, v. 32, p. 157-164, 2011. DOI: http://dx.doi.org/10.5433/1679-0359.2011v32n1p157

MARIANO, K. R.; BARRETO, L. S.; SILVA, A. H. B.; NEIVA, G. K. P.; AMORIM, S. Fotossíntese e tolerância protoplasmática foliar em Myracrodruon urundeuva Fr. All. Submetida ao déficit hídrico. Revista Caatinga, Mossoró, v. 22, n. 1, p. 72-77, 2009.https://periodicos.ufersa.edu.br/index.php/caatinga/article/view/155/pdf

MOUSTAKA, M.; OUZOUNIDOU, G.; LANNOYER, R. Indirect effects of aluminum stress on function of the photosynthetic apparatus. Plant Physiology and Biochmistry, Paris, v. 34, p. 553-569, 1996.

NOVAIS, R. F.; NEVES, J. C. L; BARROS, N. F. Ensaio em ambiente controlado. In: OLIVEIRA, A. J.; GARRIDO, W. E.; ARAÚJO, J. D.; LOURENÇO, S. (Coord.). Métodos de pesquisa em fertilidade do solo. Brasília: EMBRAPA-SEA, 1991. 189-253p.

PEREIRA, W. E.; SIQUEIRA, D. L.; MARTINEZ, C. A.; PUIATTI, M. Gas exchange and chlorophyll fluorescence in four citrus rootstocks under aluminium stress.Journal of Plant Physiology, v.157, p.513-520, 2000. https://doi.org/10.1016/S0176-1617(00)80106-6

PEREIRA, L. B.; TABALDI, L. A.; GONÇALVES, J. F.; JUCOSKI, J. O.; PAULETTO, M. M.; WEIS, S. N.; NICOLOSO, F. T.; BORHER, D.; ROCHA, J. B. T.; SCHETINGER, M. R. C. Effect of aluminum on $\delta-$ aminolevulinic acid dehydratase (ALA-D) and the development of cucumber (Cucumis sativus). Environmental and Experimental Botany, v. 57, p. 106-115, 2006.

https://doi.org/10.1016/j.envexpbot.2005.05.004

SILVA, M. M. P.; VASQUEZ, H. M.; BRESSAN-SMITH, R.; SILVA, F. C.; ERBESDOBLER, E. D. A.; JUNIOR, P. S. C. A. Eficiência fotoquímica de gramíneas forrageiras tropicais submetidas à deficiência hídrica. Revista Brasileira de Zootecnia, v. 35, n. 1, p. 67-74, 2006. http://dx.doi.org/10.1590/S151635982006000100008 
SOUSA, A. E. C.; SILVEIRA, J. A. G.; GHEYI, H. R.; LIMA NETO, M. C.; LACERDA, C. F.; SOARES, F. A. L. Trocas gasosas e conteúdo de carboidratos e compostos nitrogenados em pinhão-manso irrigado com águas residuária e salina. Pesquisa Agropecuária Brasileira, v. 47, n. 10, p. 1428-1435, 2012. https://seer.sct.embrapa.br/index.php/pab/article/view/12781/8139 https://oi.org/10.1590/S0100204X2012001000003

STRASSER, A.; TSIMILLI-MICHAEL, M.; SRIVASTAVA, A. Analysis of the fluorescence transient. In: PAPAGEORGIOU, G. C.; GOVINDJEE (eds.). Chlorophyll fluorescence: A signature of photosynthesis. Advances in Photosynthesis and Respiration Series. Dordrecht: Springer, 2004. 32-362p.

https://doi.org/10.1007/978-1-4020-3218-9_12

TABALDI, L. A.; NICOLOSO, F. T.; CASTRO, G. Y.; CARGNELUTTI, D.; GONÇALVES, J. F.; RAUBER, R.; SKREBSKI, E. C.; SCHETINGER, M. R. C.; MORSCH, V. M.; BISOGNIN, D. A. Physiological and oxidative stress responses of four potatoto aluminum in nutrient solution. Brazilian Journal of Plant Physiology, v. 19, p. 211-222, 2007. http://dx.doi.org/10.1590/S1677-04202007000300005

YANG, M.; TAN, L.; XU, Y.; ZHAO, Y.; CHENG, F.; YE, S.; JIANG, W. Effect of Low pH and Aluminum Toxicity on the Photosynthetic Characteristics of Different Fast-Growing EucalyptusVegetatively Propagated Clones. PLoS ONE, v.10, n.6, p.1-15, 2015. https://www.ncbi.nlm.nih.gov/pubmed/26090998 https://doi.org/10.1371/journal.pone.0130963 